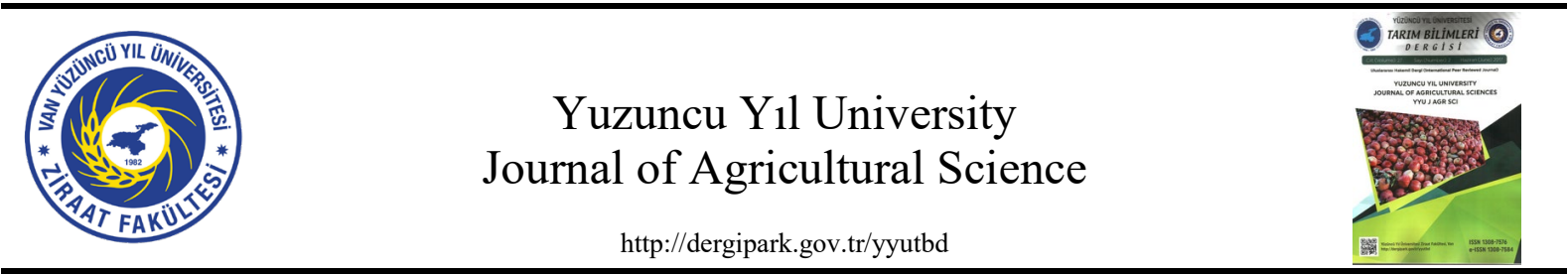

Research Article (Araştırma Makalesi)

\title{
Karasal Salyangoz (Helix lucorum L.) Midesinden Elde Edilen Enzim Bileşenleri Kullanılarak Çavdar (Secale spp.) Türlerinde Karyotip Analizi
}

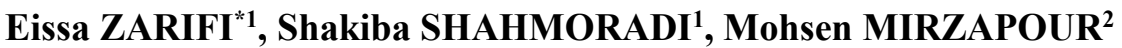

\author{
${ }^{1}$ Genetics and Genetic Resources Research Department, Seed and Plant Improvement Institute (SPII), \\ Agricultural Research \& Education Organization (AREO), Karaj, Iran \\ ${ }^{2}$ Department of Agricultural Biotechnology, Faculty of Agriculture, Siirt University, 56100, Siirt, Turkey \\ *Corresponding author e-mail: ezarifi@yahoo.com or e.zarifi@areeo.ac.ir
}

\section{Makale Bilgileri}

Geliș: 27.05.2019

Kabul: 05.11.2019

Online Yayınlanma 31.12.2019

DOI: 10.29133 /yyutbd.570576

Anahtar kelimeler

Çavdar,

Karyotip,

Kara salyangozu (Helix),

Secale,

Sitaz.
Öz: Karasal salyangoz (Helix lucorum L.), Helicidae ailesine ait, ormanlarda ve nemli bölgelerde yaşar; yaprak, ağaç kabuğu ve bol miktarda selüloz içeren bitkilerden beslenir. Karasal salyangozun sindirim sistemi, sellülözik materyali sindirebilen özel enzim bileşenlerine sahiptir. Aseto karmin, Aceto orsein, Feulgen ve farklı boyar maddeler kullanılarak yapılan kromozom ve karyotip analizi çalışmalarında, türe ait karakterlere bağlı olarak kromozom boyu, tanen miktarı ve kromozom karşılaştırmalarında sorunlar yaşanmıştır. Kara salyangozu midesinin enzimatik bileşenleri, sitoplazma ve hücre duvarı yumuşaması üzerinde etkili olmuştur. Çalışmada, çavdar (Secale spp.) bitkisine ait iki türde, en iyi ve kolay şekilde kromozomların ayrılması ve dağılması amacıyla bu bileşenler kullanılmıştır. Sitaz ve diğer enzimlerin aktif bir karışımını içeren enzimatik bileşenleri kullanmak amacıyla, karasal salyangozlar İran'ın kuzey batısındaki nemli Arasbaran Ormanları'ndan toplanmış, bileşenler elde edilmiş ve soğuk koşullarda muhafazası sağlanmıştır. İki çavdar türünün (Secale cereale L. ve S. montanum) çimlenmiş tohumlarının kök uçları $\alpha$-bromonaftalin solüsyonunda ön işleme tabi tutulmuş ve aseto-iron hematoxylin boyar madde ile boyanmıştır. Daha sonra, sitoplazmayı belirginleştirmek, hücre duvarını yumuşatmak ve tatminkar bir kromozom yayılması ve ayrılması elde etmek amaciyla kara salyangozu midesinden elde edilen enzimler kullanılmıştır. Araştırma sonucunda kara salyangozu midesinin enzimatik bileşenleri kullanılarak, her iki türde kromozomlar açık bir şekilde ayırt edilmiş ve, iyi bir metafaz safhası ve dağılımı gözlemlenmiştir. Kromozomlar bozulmadan kalırken, tüm hücrelerin tamamen ayrılması kolay bir şekilde sağlanmıştır. Çavdar türleri (Secale spp.) $2 n=2 x=14$ kromozoma sahiptir ve diploiddir. Her iki türde de satellit (uydu) kromozom vardır ve satellitler, kromozomların kısa kolları üzerinde bulunmaktadır.

\section{Karyotype Analysis of Rye (Secale spp.) Species by Using the Extracted Enzyme from the Terrestrial Snail Stomach (Helix lucorum L.)}

\section{Article Info}

Received: 27.05.2019

Accepted: 05.11.2019

Online Published 31.12.2019

DOI: $10.29133 /$ yyutbd.570576
Abstract: The snail (Helix lucorum L.) belongs to Helicidae family, lives in forests and moist regions and feeds from leaves, wood, and vegetable containing a lot of cellulose. The digestive system of this snail has special enzymatic components for digesting cellulosic materials and has some effects on cytoplasmic and cell wall digestion. Chromosomal studies and karyotypes analysis using different methods of staining (Aceto Carmine, Aceto Orcein, Feulgen and etc.) have some problems such as chromosomal size, amount of 
Keywords

Rye,

Karyotype,

Snail (Helix),

Secale,

Cytase. tannins and difficulty of contrast in chromosome detection depending on species characters. We used these components that included an active mixture of Cytase and other enzymes, for easy squashing and perfect chromosome separation in two species of rye (Secale spp.). The terrestrial snails were collected from Arasbaran humid forests (North West of Iran), and extracted the components and kept in freeze condition. The root tips of germinated seeds of two species of rye were pretreated with $\alpha$-Bromonaphtalin solution and stained in Aceto-Iron Haematoxylin. Then the enzymes were used for clearing cytoplasm and softening cell walls and to obtain sufficient squashing and chromosomes spread. The using the enzymatic components of snail stomach was very effective in squashing stage, and obtaining good metaphase plates, the chromosomes were counted and distinguished very clearly. The separation of all cells, without damaging the chromosomes, was achieved easily and completely. Species of rye (Secale spp.) were diploid with $2 \mathrm{n}=2 \mathrm{x}=14$ chromosomes. The satellited chromosomes were seen in both two species on short arms of chromosomes.

\section{Giriş}

Sitolojik çalışmalar ve kromozomların karyotip hazırlanmasında, hücre bölünmesinin metafaz evresinde, iyi ve net mikroskobik lamlar elde etmede, metafaz safhasındaki kromozomların dağılımında eksiklik, kromozomların hücre organelleri tarafindan örtülmesi, kromozomların üst üste binmesi ve aynı düzleme oturmaması ve son olarak da hücre içi eklerin varlığı gibi birçok sorun yaşanmaktadır. $\mathrm{Bu}$ sorunları gidermek, kromozom araştırmalarını iyileştirmek ve bitki ve hayvan hücrelerinden uygun karyogram elde etmek için organelleri ortadan kaldırmak ve sitoplazma çözünürlüğünü artırmak gerekmektedir. Bu amaçla, amilaz, selülaz, pektinaz ve sitaz gibi enzimler kullanılır (Sharma ve Sharma, 1980).

Yukarıda adı geçen ticari enzimlerin sağlanması ve saklanması çok yüksek maliyetli olduğu için, araştırmacılar bu sorunu giderecek yeni arayışlar içine girmişlerdir. Bu doğrultuda da salyangoz gibi hayvanlar sindirim sisteminde üretilen enzimlerin daha elverişli ve daha ucuz elde edilir olmasından dolayı tercih edilmeye başlanmıştır (Greathouse, Klemme ve Barker, 1942; Niranjan ve Roy, 1982).

$\mathrm{Bu}$ araştırmada kullanılan kara salyangozuna, çoğunlukla rutubetli bölgelerde bulunan bahçe salyangozu (Helix lucorum L.) adı da verilmektedir. Bu salyangozun sindirim sisteminde salgılanan enzim, amilaz, selülaz ve pektinaz karışımıdır ve selüloz ve pektin maddelerini ayrıştırma özelliğine sahiptir (Dorit ve ark., 1991; Moyes ve Schulte, 2008).

$\mathrm{Bu}$ araştırmada karasal salyangozun (Helix lucorum L.) sindirim sisteminden elde edilen enzim karışımı, Graminae familyasından olan iki tür çavdarın (Secale spp.) kromozomlarının incelenmesi sırasında ezme mikroskobik preparat ve görüntü hazırlama aşamasında kullanılmıştır. $\mathrm{Bu}$ bitkinin tohumu insan ve hayvan beslenmesinde kullanılır ve İran'da 6 türü mevcuttur (Rechinger, 1973; Khodabande, 2013).

Karasal Salyangozun (Helix lucorum L.) Zoolojik Sinfflandırılmast: Karasal salyangoz, omurgasizlar (Invertebrate) sinıfindan, yumuşakçalar (Teomophidea) grubundan, gastropoda kategorisinden, tek kutuplu yumuşakcıklar'dan (Mollusks univalve) ve (Helicidae) familyasına ait bir türdür. (Dorit ve ark., 1991; Moyes ve Schulte, 2008; Schmidt-Nielsen, 1997). Dünyada tespit edilen gastropoda türü yaklaş1k 35000 türdür (Dorit ve ark., 1991; Miller ve Harley, 1992; Salahi Moghaddam, 2009). Gastropodaların çoğu denizde yaşar, ancak bunlardan bazıları tatlı suda, bazıları da karada yaşamaya adapte olmuşlardır. Salyangozlar ise genellikle karada yaşarlar (Pruitt, Underwood, ve Surver, 2000).

Salyangozun Morfolojik Özellikleri: Yumuşak beden ile kalsiyum karbonattan oluşan sert bir kabuk normal salyangozların ortak özellikleridir (Russel-Hunter, 1979). Bu salyangozun görünürde bir ayakbaş kısmı vardır ve baş, bu kısmın en önünde konumlanarak iki çift anten (1 çift duyusal ve bir çift de görsel) ile diğer kısımlardan ayrılmıştır. Ağız yarık benzeri bir deliktir ve tam olarak ayak - baş kısmının ön alt bölümündedir ve çok belirgin değil (Karami, 2000). Bu salyangoz karada yaşar ve yetişkin bir salyangozun kabuk çapı 3 ile 5 santimetre arasında değişmektedir (Dalili, 2005). Kabuğunun rengi kahve tonundadır (Shekoohinezhad ve Amin, 1973). 4 adet anteni mevcuttur ve gözler arka antenlerin üstünde yer almıştır. Bu salyangoz karın kaslarındaki dalgalanma hareketinin 
yardımıyla, ağzının altında var olan bezden salgılanan mukoza dolu bir yol üzerinde yavaş ve sabit bir hızla ilerlemektedir. (Shekoohinezhad ve Amin, 1973; Habibi, 2015).

Karasal Salyangozun Iran'da Yaşam Alanı ve Dağılımı: Bu salyangoz ormanlarda ve rutubetli bölgelerde yaşayıp selülozu bol olan yaprak, ağaç, yeşil bitki ve benzeri maddelerle beslenir. $\mathrm{Bu}$ maddeleri ağzındaki tükürükle 1slatıp çenesiyle tutarak küçük radula dişleriyle küçük parçalara ayırıp ufaltır (Storer ve ark., 1968; Moyes ve Schulte, 2008; Habibi, 2015). Salyangozlar genellikle gece saatlerinde ve rutubetli havalarda daha aktif olurlar ve kaslı bacaklarındaki kasılma dalgalarıla hareket ederler (Storer ve ark., 1968). İran'da bu tür kuzeybatı ormanlarında (Karadağ Bölgesi) 1500 metre yükseklikte bulunmaktadır.

Sindirim Sistemi: Karasal salyangozda sindirim ağızdan başlar. Sistem, kaslı bir boğaz, sert bir çene, dil yerine geçen ve Radula denilen bir organ ve birkaç sıra kitinsel küçük dişlerden oluşur (Karami, 2000; Storer ve ark., 1968). Taşlığın hizasında iki adet tükürük bezi mevcuttur. Bu bezlerin salgıladığı enzimler yemek borusunun ön kısmına akar. Bu bezler kısmen sulu ve çeşitli enzimler ihtiva eden müköz salgılar. Taşlığa aynı zamanda sindirim bezlerinin salgıları da dökülür. Bu salyalar arkaya doğru akar, aynı zamanda kahverengi olan, sitaza benzeyen ve selülozun hazmedilmesine yarayan bir enzim de içerir (Karami, 2000). Gıda maddelerinin sindirimi büyük ölçüde hücre dışında gerçekleşir ve midede bulunan bezlerden salgılanan enzimler vasitasıyla yapılır. Sindirim sisteminin diğer kısımları hücre içinde ve sindirim sekumu içinde yapılır (Dorit ve ark., 1991).
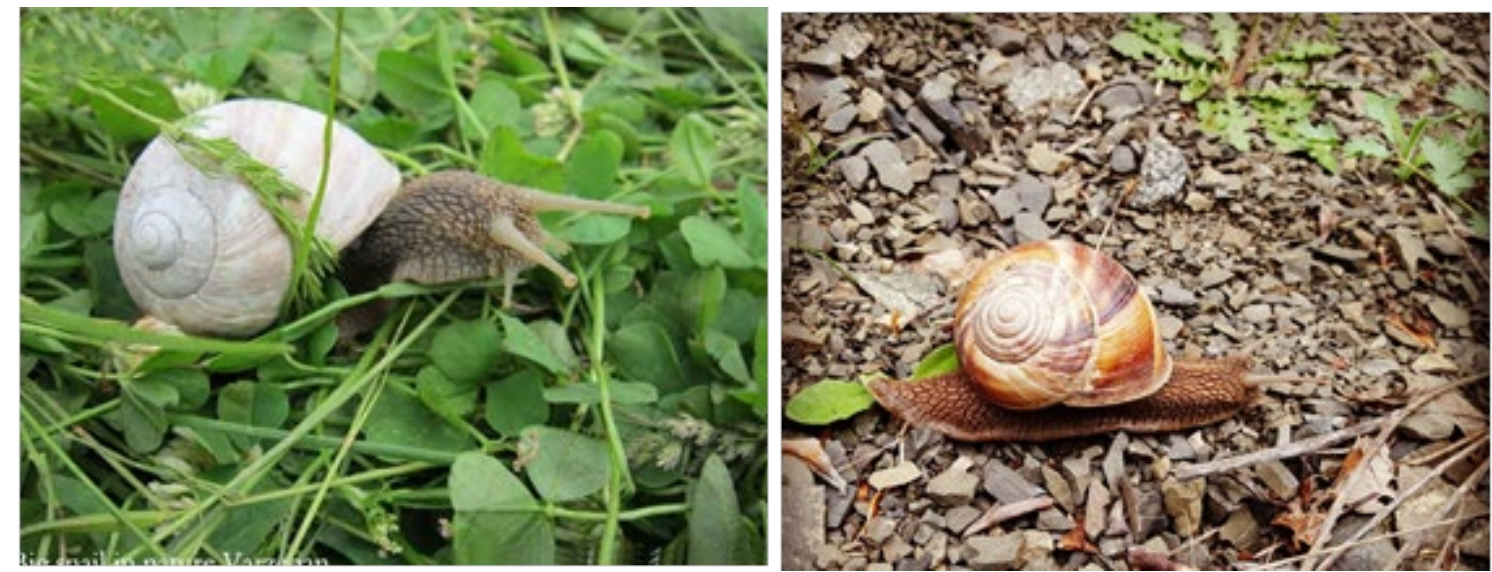

Şekil 1. Karasal Salyangozunun (Helix lucorum L.) Antenleri ve Morfolojisi, (Kaleibar, Arasbaran, 1500 metre) (Negah Media, 2013).

\section{Materyal ve Yöntem}

\subsection{Materyal}

$\mathrm{Bu}$ çalışmada kullanılan salyangozlar İran'ın kuzeybatısında (Karadağ, Arasbaran) yer alan 1500 metre yükseklikteki rutubetli ormanlardan toplanıp daha sonra sitogenetik laboratuvarlara aktarılmıştır. Salyangozların birkaç örneği, türünün tespit edilmesi amacıyla, Tahran Sağlık Bilimleri Üniversitesi'ne bağlı Medical Malacology laboratuvarına gönderilmiş ve türü tespit edilmiştir.

Sitogenetik incelemelerin yapılması amaciyla çavdar türlerinin (TN00022; Secale cereale L. ve TN00052; S. montanum Guss.) tohumları İran Ulusal Gen Bankası'ndan temin edilmiştir.

\subsection{Yöntem}

Kara salyangozlarından sitaz enzimi elde etmek ve midenin enzim ve asit salgılamasını sağlamak amaciyla sözkonusu salyangozlar 48 saat boyunca aç tutulduktan sonra salyangozun gövdesi kabuğundan ayrılarak iç organları dışarı çıkarılmıştır. Midede bulunan maddeler özel kap içine alınmış ve fazla maddeleri enzimden ayırmak için santrifüj işlemi uygulanmış, tekrar tüpler içine konularak sıfırın altında sıcaklıkta muhafaza edilmiştir. İki tür çavdarın (Secale cereale L. \& S. montanum Guss.) 
kromozomlarının incelenmesi amacıyla tohumlar ilk olarak 1:9 oranında çamaşır suyunda 30 dakika boyunca dezenfekte edilmiş ve kök meristemler elde etmek için $20^{\circ} \mathrm{C}$ petri filtre kağıt üzerinde çimlendirilmişlerdir. Çimlenen tohumlardan elde edilen kök ucu meristemlerin 3 saat boyunca ve 4 santigrat derecede \%1 Alfa-bromo-naftalen solüsyonunda ön işlemi yapılmış Lewitsky solüsyonunda bekletilmişlerdir (Agayev ve ark., 2010; Zarifi ve ark., 2006; Zarifi ve Güloğlu, 2016). Daha sonra, kök uçları 1 Normal $\mathrm{NaOH}$ çözeltisinde $60^{\circ} \mathrm{C} 10$ dakika boyunca hidroliz edilmişler ve Aceto Iron Hematoksilin ile $30-32^{\circ} \mathrm{C} 16$ saat boyunca boyanmışlardır (Dirihan ve ark., 2014; Zarifi ve Güloğlu, 2016). Mikroskobik incelemeler yapmak amacıyla hücre duvarını, hücre ekleri ve organelleri ayırmak için boyanmış köklerin meristem uçları cam kaplara konulmuş ve üstlerine birer damla kara salyangozunun (Helix lucorum L.) midesinden elde edilen enzimden damlatılmış ve $30^{\circ} \mathrm{C}$ yarım saat boyunca tutulmuşlardır. Daha sonra mikroskobik ezme preparatlar hazırlanmıştır. Elde edilen ezme preparatlardan uygun metafaz saftasındaki hücrelerde Zeiss Axiophot mikroskobu kullanılarak karyotip analizi yapılmıştır. Kromozomların uzunluğu, Micro Measure 3.3 yazılımı kullanılarak 10 metafaz plakasında ölçülmüştür (Reeves, 2001) Karyotip verileri SPSS v20 ve Excell 13 (Microsoft Excell) programları kullanılarak analiz edilmiştir. Kromozom tiplerinin isimlendirilmesinde Levan yöntemiyle sentromere pozisiyona göre yapılmıştır (Levan ve ark., 1964).

\section{Sonuçlar ve Tartışma}

\section{1. Çavdar Türlerinin Sitogenetiği}

Çavdar (Secale spp.) Triticeae oymağında, buğdaygil familyasının (Poaceae (syn. Gramineae)) bir üyesidir. Secale küçük ama önemli bir tahıl cinsidir. Kültürü yapılan çavdar (S. cereale L.), ve çeşitli yabani çavdar türlerinden oluşur, olumsuz iklim koşullarında dayanıklılığ ve verimi buğdaydan daha yüksek olabilir. Bu nedenle çavdar yüksek rakımlarda, zayıf topraklarda ve kışların şiddetli olduğu bölgelerde temel tahıl ürünü olmuştur (Fageria, 1992; Tang ve ark., 2011). Yabani ve yabani ot çavdar türleri, yetiştirilen türlerin gelişimi için geniş bir genetik çeşitlilik kaynağı oluşturmaktadır (Meier ve ark., 1996).

Bu çalışmada, iki önemli Çavdar türünün (Secale cereale L. ve S. montanum Guss.) kromozom sayılarını ve karyotip özelliklerini net bir şekilde belirleyebilmek icin ileri bir teknik (Aceto-Demir-Hematoksilin boyasi) ve bu yöntemle birlikte kara salyangozu mide sıvisı kullanılmıştır. Her iki Çavdar türünün somatik kromozom sayısı, $14(2 \mathrm{x}=2 \mathrm{n}=14)$ ve ploidi seviyesi diploid olarak tespit edilmiştir ve diğer raporlarla bağdaşmaktadır (Riley, 1955; Stutz, 1957; Khush, 1962, 1963; Kranz, 1976; Masoud ve Ali-Jarrahei, 2008).

Somatik kromozom sayıları, kromozom uzunlukları, karyotip formülleri ve total karyotip uzunluğu ve asimetri indeksleri (A1, A2) (Zarco, 1986)' ya göre belirlenmiştir. Secale cereale L. ve $S$. montanum Guss. türleri icin karyomorfolojik parametreler, metafaz kromozomları ve haploid idiyogramlar sırasıyla Çizelge 1; Şekil 1 ve Şekil 3de gösterilmiştir. Bu türlerin kromozomları iyi boyanmış ve kromozomlar tek tek tanınabilir. Kromozom morfolojisi bakımından, 13 ve 14 numaralı kromozomların (çift 7) kısa kolları üzerinde iki çift uydu bulunmaktadır (Şekil 1 ve Şekil 3). Bu uydular diğer kromozomlarda, kromozomal işaretleyici olarak kullanılabilir. Türler arasında yapılan varyans analizi, bütün kromozomların uzunluk özelliği ile kısa ve uzun kollarının boyutunun \% 1 düzeyinde anlamlı olduğunu göstermiştir (Çizelge 1).

$\mathrm{Bu}$ iki türün karyogramını hazırladıktan sonra, 6 metafaz plaka kullanarak, kromozomların türü Levan ve ark. (1964)'nın kullandığı yöntemle tespit edilmiş ve $S$. montanum Guss. ve S. cereale L. türlerinde en uzun kromozomun uzunluğu sirasiyla $11.85 \pm 0.06$ ve $15.88 \pm 1.18$ mikron olarak ve kromozom türü de metasentrik olarak belirlenmiştir. En kısa kromozom türü de sırasıyla $9.86 \pm 0.08$ ve $12.64 \pm 0.61$ mikron olarak ve kromozom türü de submetasentrik olarak gözlenmiştir. Her iki türde toplam yedi çift kromozomdan, satellite olan ve yedinci sırada yer alan bir çift kromozom submetasentrik olarak belirlenmiştir. Diğer kromozomlar, S. cereale L. türünde beş metasentrik ve bir submetasentrik, $S$. montanum Guss. türünde de ise 4 metasentrik ve 2 submetasentrik kromozumdur. Her iki türde de (S. montanum Guss. ve $S$. cereale L.) kromozomların ortalama uzunluğu ve kol oranı ortalaması eşittir. Bu türlerin kromozom özellikleri 1 ve 2 numaralı cetvellerde gösterilmiştir. 


\subsection{Salyangozdan Elde Edilen Sitaz Enziminin Etkisi}

Yüz yıldan az bir sürede, bitkilerin sitogenetĭgi, türün kromozom sayısı ve morfolojisinin tanımından, moleküler karyotipleme çalışmalarına (çeşitli DNA problarının fiziksel eşlemeleri ile kromozomların tanımlanması) kadar oldukça yol almıştır. Bitki sitogenetiğinin geliştirilmesinde önemli bir adım, kromozomların boyanması ve uygun preparatların elde edilmesine yönelik yöntemlerin uygulanmasıdır (Zarifi ve Güloğlu, 2016; Zarifi ve Gharesheikhbayat, 2018). Bölünme halinde olan hücrelerin içindeki organeller, kromozomların detaylı bir şekilde incelenmesini engellemektedir. Karyotip incelemesi için kök hazırlığı süreçlerinin (ön işlem, fiksasyon, hidroliz ve boyama) hiçbiri, hücre içi maddeler ve organellerin ortadan kaldırılması ve elemine edilmesinde etkili rol oynamamaktadır. Bu nedenle hücre içinde fazladan var olan maddeler, kromozomların metafaz safhalarında uygun ve düzenli dağılımını da engellemekte ve bu durumda kromozomlar toplu ve birbirine yapışı bir şekilde görünmektedir (Koçyiğit ve Alp, 2018). Bu sebeplerle kromozomların gerçek morfolojilerini görmek mümkün olmamaktadır.

Araştırmalar, salyangozun sindirim sisteminden elde edilen salgının boyalı köklerde kullanılmasının, sitoplazmada şeffaflık ve netliğe, ayrıca hücre bölünme aşamasında kromozomların düzenli bir şekilde dağılmasına neden olduğunu göstermektedir. Salyangozun çevremizde bol miktarda bulunduğu dikkate alınırsa, çok düşük maliyetli olan bu yöntemle daha kaliteli preparatlar elde etmek mümkündür (Şekil 1).

$\mathrm{Bu}$ araştırmadan elde edilen sonuçlar, (Chambers, 1955; Myers ve Northcote, 1958; Quinn ve Rattenbury, 1972) tarafindan yapılan araştırma sonuçlarına benzemektedir. Karasal salyangoz Helix lucorum L.'nin mide sıvısında çok aktif bir sitaz ve diğer enzim karışımı bulunmaktadır. Bu sıvı, kök uçlarının ve diğer benzer bitki dokularının ezme preparatları için ideal bir yumuşatıcı ortam oluşturur. Tüm hücrelerin tamamen ayrılması kolayca sağlanırken kromozomlar etkilenmemiş ve kolaylıkla sayılmış ve çok açık bir şekilde ayırt edilmiştir. Bu sıvıyı kullanma yöntemi açıklanmaktadır; skuaş yönteminde kullanılan standart fiksasyon ve boyalar herhangi biri ile birlikte uygulanabilir. Salyangozun mide enzimi maserasyonu rutin amaçlar için oldukça zordur.

Bu çalışmanın amacı yeni bir teknik tanımlamak değil, sitologların dikkatini birçok kullanıma sahip olan yeni bir reaktife çekmektir. Bu yöntemin üstün özelliği, etkin biçimde sınırsız güvenlik marjıdır $\mathrm{Bu}$ da, tüm hücrelerin tamamen ayrılmasını etkileyecek şekilde kullanılmasını sağlamasıdır. Hazırlanan kromozomların kimyasal yapısının etkilenmemesi ve son derece berrak preparasyonların örneğin ultraviyole absorpsiyon çalışmasında kullanılması muhtemel görünmektedir.

Çizelge 1. İran'dan çavdar türlerin (Secale cereale L. \& S. montanum Guss.) somatik kromozomların parametreleri.

\begin{tabular}{|c|c|c|c|c|c|c|c|c|c|c|}
\hline \multicolumn{11}{|c|}{ Secale cereale $\mathrm{L}$. } \\
\hline Çift No & Total $(\mathrm{L}+\mathrm{S}) \mu \mathrm{m}$ & Uzun $\operatorname{kol}(\mathrm{L}) \mu \mathrm{m}$ & $\operatorname{Kisa~kol~(S)~} \mu \mathrm{m}$ & $\begin{array}{l}\text { Kol Orani } \\
(\mathrm{AR}=\mathrm{L} / \mathrm{S})\end{array}$ & $\mathrm{CI}(\mathrm{S} * 100 /(\mathrm{L}+\mathrm{S}))$ & Sat & Tip & $\mathrm{L} \%$ & $\mathrm{~S} \%$ & RL\% \\
\hline 1 & $15.88 \pm 1.18$ & $8.51 \pm 0.74$ & $7.37 \pm 0.5$ & $1.15 \pm 0.05$ & 47 & & $\mathrm{~m}$ & 8.41 & 7.28 & 15.70 \\
\hline 2 & $15.72 \pm 0.84$ & $10.45 \pm 0.66$ & $5.27 \pm 0.32$ & $2 \pm 0.14$ & 34 & & $\mathrm{sm}$ & 10.33 & 5.21 & 15.54 \\
\hline 3 & $15.08 \pm 0.77$ & $9.51 \pm 0.46$ & $5.56 \pm 0.36$ & $1.72 \pm 0.07$ & 37 & & $\mathrm{sm}$ & 9.40 & 5.50 & 14.91 \\
\hline 4 & $14.09 \pm 0.42$ & $9.86 \pm 0.32$ & $4.24 \pm 0.1$ & $2.33 \pm 0.03$ & 30 & & $\mathrm{sm}$ & 9.75 & 4.19 & 13.93 \\
\hline 5 & $14.41 \pm 1.09$ & $7.9 \pm 0.91$ & $6.51 \pm 0.19$ & $1.21 \pm 0.11$ & 46 & & $\mathrm{~m}$ & 7.81 & 6.43 & 14.24 \\
\hline 6 & $13.35 \pm 0.78$ & $7.12 \pm 0.48$ & $6.23 \pm 0.35$ & $1.14 \pm 0.05$ & 47 & & $\mathrm{~m}$ & 7.04 & 6.16 & 13.20 \\
\hline 7 & $12.64 \pm 0.61$ & $7.78 \pm 0.4$ & $3.63 \pm 0.29$ & $2.16 \pm 0.07$ & 29 & 1.23 & $\mathrm{sm}$ & 7.69 & 3.59 & 12.49 \\
\hline Mean & $14.45 \pm 0.36$ & $8.73 \pm 0.3$ & $5.54 \pm 0.26$ & $1.67 \pm 0.09$ & & & & & & \\
\hline \multicolumn{2}{|c|}{ Total $(\mathrm{TC})=101.17$} & & & & & & & 60.42 & 38.36 & \\
\hline \multicolumn{11}{|c|}{ S. montanum Guss. } \\
\hline 1 & $11.85 \pm 0.06$ & $6.33 \pm 0.09$ & $5.52 \pm 0.08$ & $1.15 \pm 0.03$ & 47 & - & $\mathrm{m}$ & 8.44 & 7.36 & 15.80 \\
\hline 2 & $11.27 \pm 0.20$ & $7.11 \pm 0.2$ & $4.16 \pm 0.14$ & $1.72 \pm 0.09$ & 37 & - & $\mathrm{sm}$ & 9.48 & 5.55 & 15.03 \\
\hline 3 & $10.77 \pm 0.13$ & $7.21 \pm 0.1$ & $3.56 \pm 0.22$ & $2.05 \pm 0.14$ & 33 & - & $\mathrm{sm}$ & 9.61 & 4.75 & 14.36 \\
\hline 4 & $10.93 \pm 0.13$ & $5.93 \pm 0.13$ & $5.00 \pm 0.16$ & $1.19 \pm 0.06$ & 46 & - & $\mathrm{m}$ & 7.91 & 6.67 & 14.58 \\
\hline 5 & $10.18 \pm 0.22$ & $6.83 \pm 0.19$ & $3.35 \pm 0.27$ & $2.09 \pm 0.19$ & 33 & - & $\mathrm{sm}$ & 9.11 & 4.47 & 13.58 \\
\hline 6 & $10.13 \pm 0.18$ & $5.21 \pm 0.15$ & $4.91 \pm 0.05$ & $1.06 \pm 0.03$ & 49 & - & $\mathrm{m}$ & 6.95 & 6.55 & 13.51 \\
\hline 7 & $9.86 \pm 0.08$ & $5.6 \pm 0.11$ & $2.79 \pm 0.08$ & $2.01 \pm 0.08$ & 28 & 1.47 & $\mathrm{sm}$ & 7.47 & 3.72 & 13.15 \\
\hline Mean & $10.71 \pm 0.14$ & $6.32 \pm 0.15$ & $4.18 \pm 0.19$ & $1.61 \pm 0.09$ & & & & & & \\
\hline \multicolumn{2}{|c|}{ Total $(\mathrm{TC})=74.99$} & & & & & & & 58.97 & 39.06 & \\
\hline
\end{tabular}

L: Kromozom uzun kol uzunluğu $(\mu \mathrm{m})$, S: Kromozomun kısa kol uzunluğu $(\mu \mathrm{m})$, CI: Sentromer indeksi, (m: Metasentrik, sm : Submetasentrik); Levan ve ark. (1964 )'a göre sentromer tipi, Sat: Satellit, N: Karyotip belirlemede kullanılan mitotik metafaz sayısı, L\% ve S\%: Her bir kromozom için her kolun ne oranda olduğunu gösteren indeksler, RL\%: Göreli kromozom boyları. 


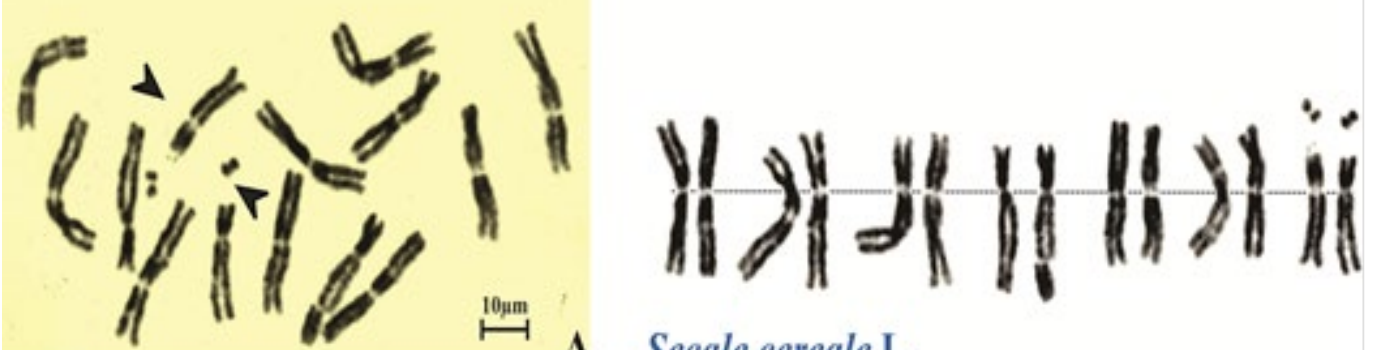

A Secale cereale $\mathrm{L}$.

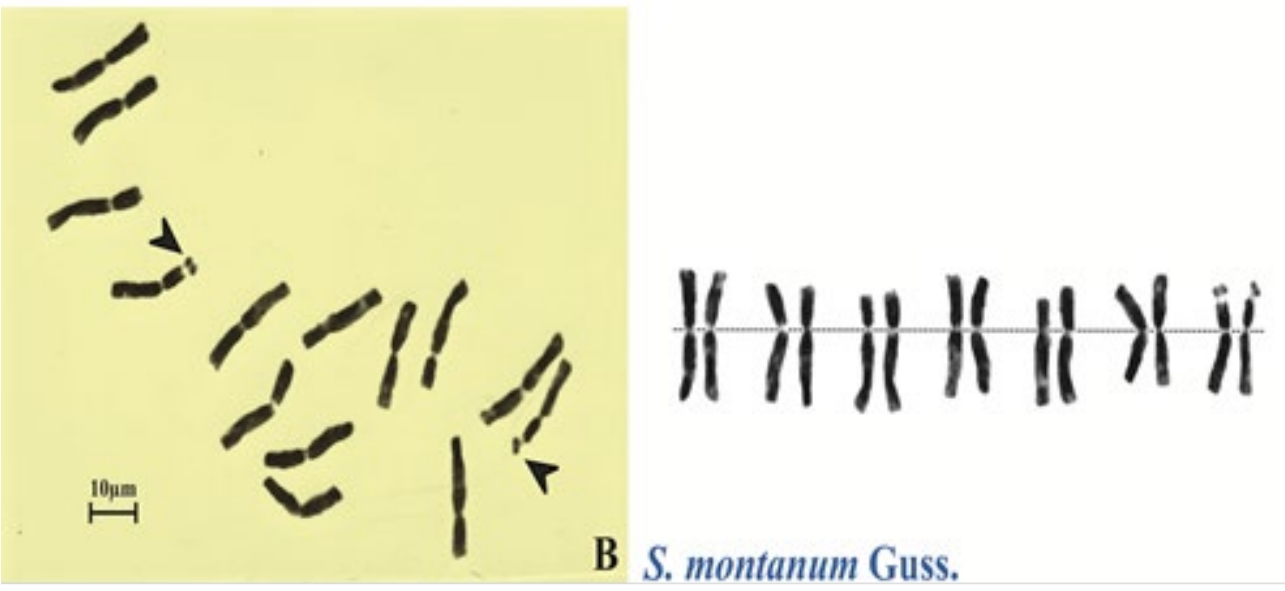

Şekil 1. A: Secale cereale L., B: S. montanum Guss. $(2 \mathrm{n}=2 \mathrm{x}=14)$; kromozomların mitotik metafaz da yayılışı ve elde edilmiş karyogramları sağda, Satelitli kromozomlar, sekiller uzerinde oklarla işaretlenerek gösterilmiştir.

Çizelge 2. İran'dan çavdar türlerin (Secale cereale L. \& S. montanum Guss.) karyotip özellikleri

\begin{tabular}{|c|c|c|c|c|c|c|c|c|c|c|c|c|c|}
\hline Türler & KF & Ortalama(TL) & Aralığ 1 & $\mathrm{TC}$ & $\mathrm{CI}$ & SAT & $\mathrm{CV} \%$ & AI & $\mathrm{A}_{1}$ & $\mathrm{~A}_{2}$ & DRL & $\mathrm{TF} \%$ & $\mathrm{SC}$ \\
\hline 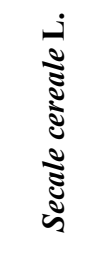 & 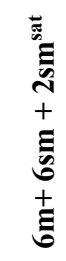 & 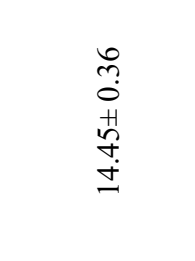 & 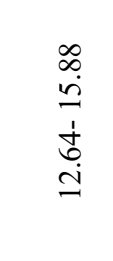 & 101.17 & 38 & 1.23 & 7.70 & 0.222 & 0.43 & 0.08 & 3.04 & 38.36 & $3 \mathrm{~A}$ \\
\hline 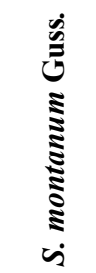 & 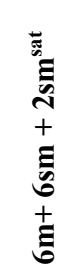 & $\begin{array}{l} \pm \\
\dot{0} \\
+ \\
\stackrel{+}{*} \\
0\end{array}$ & $\begin{array}{l}\mathscr{\infty} \\
\stackrel{0}{=} \\
\dot{b} \\
\infty \\
a\end{array}$ & 74.99 & 39 & 1.47 & 6.12 & 0.202 & 0.41 & 0.06 & 2.65 & 39.06 & $3 \mathrm{~A}$ \\
\hline
\end{tabular}

Karyotip Formülü (KF), Ortalama Kromozom Uzunluğu (Ortalama (TL)), Satelit Boyu (SAT), Haploid kompleman toplam kromozom boyu (TC), kromozom uzunluğunun aralığı (Aralı̆̆ı), $\mathrm{A}_{1}$ intrakromozomal asimetri (intrachromosomal asymmetry) indeksi ve $\mathrm{A}_{2}$ interkromozomal asimetri (interchromosomal asymmetry) indeksi (Zarco, 1986), Ortalama Sentromerik indeks (CI), Stebbins kategorileri asimetrisi (SC) (Stebbins, 1971), Karyotipin toplam formu yüzdesi ( TF\%)(Huziwara, 1962), Varyasyon Katsayıs1 (CV\%), karyotip asimetri indeksi (AI) (Paszko, 2006; Watanabe, Yahara, Denda, and Kosuge, 1999) ve Nispi kromozom boyunun aralık farkı (DRL). 


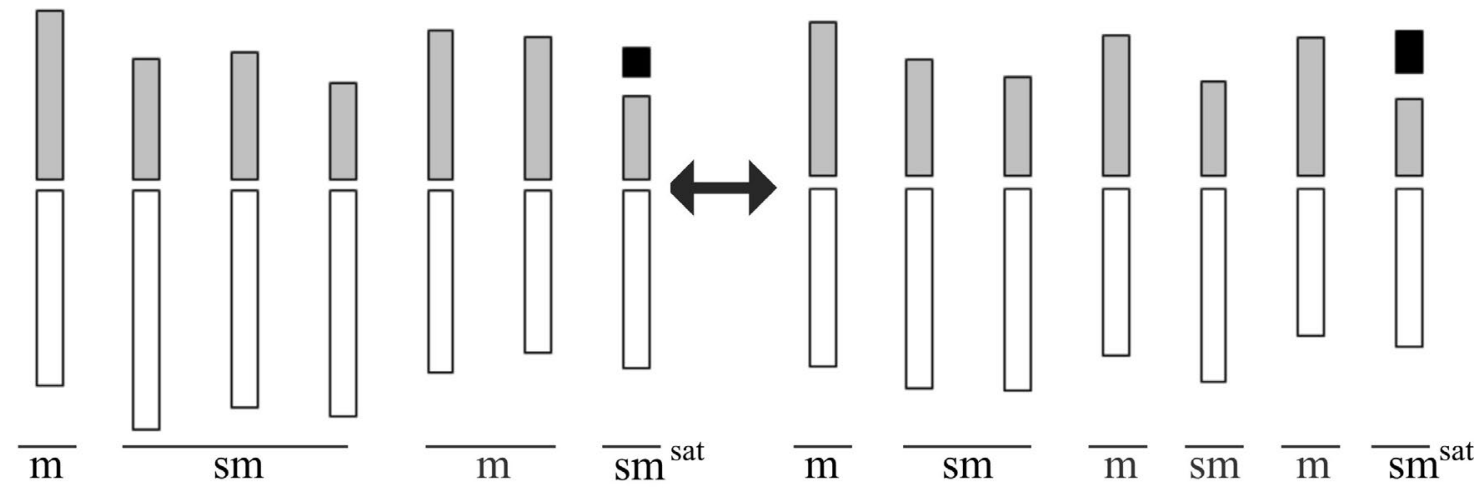

Secale cereale $\mathrm{L}$.

S. montanum Guss.

Şekil 2. Çalış1lan çavdar türlerinin haploid ideogramı (Secale cereale L. \& S. montanum Guss.) 2n=2x=14, $\mathrm{x}=7$

\section{Teşekkür}

Bu çalışma, Genetik Araştırma ve İran Ulusal Bitki Gen Bankası (SPII) tarafından desteklenen projenin (7-03-03-92318) parçasıdır.

\section{Kaynaklar}

Agayev, Y. M., Zarifi, E., \& Fernández, J. A. (2010). A study of karyotypes in the crocus sativus L. Aggregate and origin of cultivated saffron. Acta Horticulturae, 850(850), 47-54.

Chambers, T. C. (1955). Use of snail stomach cytase in plant cytology. Nature, 175(4448), 215.

Dalili, G. H. (2005). Animal classification. Sokhan Gostar, Tehran (In Persian).

Dirihan, S., Zarifi, E., Güloğlu, D., \& Sevimay, C. S. (2014). Karyotype Features of Berseem Clover (T. alexandrinum L.) and Persian Clover (T. resupinatum L.) Species Which Cultivated in Turkey. Tarım Bilimleri Araştırma Dergisi, 7(1), 49-54. Retrieved from www.nobel.gen.tr

Dorit, R., Walker, W. F. (Warren F., \& Barnes, R. D. (1991). Zoology (Internatio). Philadelphia: Saunders College Pub.

Fageria, N. K. (1992). Maximizing Crop Yields. Taylor \& Francis. Retrieved from

Greathouse, G. A., Klemme, D. E., \& Barker, H. D. (1942). Determining the deterioration of cellulose caused by fungi improvements in methods. Industrial and Engineering Chemistry - Analytical Edition, 14(8), 614-620.

Habibi, T. (2015). General Zoology Volume II worms and molluscs. Tehran University, Tehran (In Persian).

Huziwara, Y. (1962). Karyotype analysis in some genera of compositae. VIII. Further studies on the chromosomes of aster. American Journal of Botany, 49(2), 116-119.

Karami, M. (2000). Invertebrate Zoology. Shahed University, Tehran ( In persian).

Khodabande, N. (2013). Cereals. Tehran University ( In Persian).

Khush, G. S. (1962). Cytogenetic and Evolutionary Studies in Secale. II. Interrelationships of the Wild Species. Evolution, 16(4), 484.

Khush, G. S. (1963). Cytogenetic and evolutionary studies in Secale III. Cytogenetics of weedy ryes and origin of cultivated rye. Economic Botany, 17(1), 60-71.

Koçyiğit, M., \& ALP, Ş. (2018). Tıbbi ve Süs Bitkisi Olan Vaccaria hispanica' nın Tohum Morfolojisi, Yaprak Anatomisi ve Karyotip Analizi. Yüzüncü Yll Üniversitesi Tarım Bilimleri Dergisi, 28(1), 10-18.

Kranz, A. R. (1976). Karyotype analysis in meiosis: Giemsa banding in the genus Secale L. Theoretical and Applied Genetics, 47(3), 101-107.

Levan, A., Fredga, K., \& Sandberg, A. A. (1964). Nomenclature for centromeric position on chromosomes. Hereditas, 52(2), 201-220.

Masoud, S., \& Ali-Jarrahei, S. (2008). Cytogenetical studies of some species of the genus Secale L. 
(Poaceae) in Iran. Caryologia, 61(2), 182-189.

Meier, S., Kunzmann, R., \& Zeller, F. J. (1996). Genetic variation in germplasm accessions of Secale vavilovii Grossh. Genetic Resources and Crop Evolution, 43(1), 91-96.

Miller, S. A., \& Harley, J. P. (1992). Zoology. Wm. C. Brown.

Moyes, C. D., \& Schulte, P. M. (2008). Principles of Animal Physiology. Pearson Education. Retrieved from http://books.google.com/books?id=f-INSQAACAAJ\&pgis=1

Myers, F. L., \& Northcote, D. (1958). A survey of the enzymes from the gastro-intestinal tract of Helix pomatia. Journal of Experimental Biology, 35(3), 639-648. Retrieved from Negah Media. (2013). Retrieved August 31, 2018, from

Niranjan, A. R. S., \& Roy, S. K. (1982). The Use of Stomach Cytase from the Water Snail Pila Globosa in Root Tip Squashes of Ferns. Stain Technology, 57(3), 188-190.

Paszko, B. (2006). A critical review and a new proposal of karyotype asymmetry indices. Plant Systematics and Evolution, 258(1-2), 39-48.

Pruitt, N. L., Underwood, L. S., \& Surver, W. (2000). BioInquiry: Making Connections in Biology. John Wiley. Retrieved from https://books.google.com/books?id=eh5FAQAAIAAJ

Quinn, C. J., \& Rattenbury, J. A. (1972). Structural hybridity in New Zealand dacrydium. New Zealand Journal of Botany, 10(3), 427-436.

Rechinger, K. H. (1973). Gramineae. Flora Iranica, 30-70.

Reeves, A. (2001). MicroMeasure: A new computer program for the collection and analysis of cytogenetic data. Genome, 44(3), 439-443.

Riley, R. (1955). The cytogenetics of the differences between some Secale species. The Journal of Agricultural Science, 46(3), 377-383.

Russel-Hunter, W. D. (1979). A life of invertebrates. Macmillan Publishers Limited.

Salahi Moghaddam, A. R. (2009). Medical malacology. Hormozgan University (In persian).

Schmidt-Nielsen, K. (1997). Animal physiology: adaptation and environment. Cambridge University Press.

Sharma, A. K., \& Sharma, A. (1980). Chromosome Techniques: Theory and Practice (3rd ed.). Butterworth \& Co (Publishers) Ltd, London.

Shekoohinezhad, M., \& Amin, A. (1973). Animal Biology. Amir Kabir Publishing institue, Tehran (In Persian).

Stebbins, L. G. (1971). Chromosomal Evolution in Higher Plants. Edward Arnold Ltd. London: Edward Arnold Ltd., Retrieved from http://books.google.co.uk/books/about/Chromosomal evolution in higher plants.html?id=Fg cBAAAAMAAJ

Storer, T. I. (Tracy I., Nybakken, J. W., \& Usinger, R. L. (Robert L. (1968). Elements of Zoology (3rd ed.). McGraw-Hill.

Stutz, H. C. (1957). A cytogenetic analysis of the hybrid Secale cereale L. x Secale montanum Guss. and its progeny. Genetics, 42(3), 199.

Tang, Z. X., Ross, K., Ren, Z. L., Yang, Z. J., Zhang, H. Y., Chikmawati, T., \& Gustafson, J. P. (2011). Secale. In Wild Crop Relatives: Genomic and Breeding Resources (pp. 367-396). Berlin, Heidelberg: Springer Berlin Heidelberg.

Watanabe, K., Yahara, T., Denda, T., \& Kosuge, K. (1999). Chromosomal Evolution in the Genus Brachyscome (Asteraceae, Astereae): Statistical tests regarding correlation between changes in karyotype and habit using phylogenetic information. J. of Plant Research, 112(2), 145-161.

Zarco, C. R. (1986). A new method for estimating karyotype asymmetry. Taxon, 35(3), 526.

Zarifi, E., Aghyev, Y., Ghanavati, F., \& Aminizadeh, Z. (2006). Cytogenetics and evolution of karyotype in wormwood, Artemisia vulgaris L. Seed and Plant Improvment Journal, 22(1), 112.

Zarifi, E., \& Güloğlu, D. (2016). An improved Aceto-Iron-Haematoxylin staining for mitotic chromosomes in Cornelian cherry (Cornus mas L.). Caryologia, 69(1), 67-72.

Zarifi, E., \& Gharesheikhbayat, R. (2018). New Chromosome counting of a natural hybrid or new member in Prunus genus (P. cerasifera $\times$ P.spp.) and Chromosomal similarities with two closely related species. Yüzüncü Yıl Üniversitesi Tarım Bilimleri Dergisi, 28(Special), 340348. 